\title{
THE INFLUENCE OF CORPORATE SOCIAL RESPONSIBILITY AND CORPORATE GOVERNANCE TO FIRM VALUE BY TAX AVOIDANCE AS INTERVENING VARIABLE
}

\author{
Fadhilah Moch. Fatkur*, Sukoharsono Eko Ganis, Nuzula Nila Firdausi \\ Faculty of Administrative Science, University of Brawijaya, Indonesia \\ ${ }^{*}$ E-mail: fatkur fadhilah@yahoo.com
}

\begin{abstract}
This study examines the assessment of Indonesian companies on Corporate Social Responsibility and Corporate Governance on all samples of State-ownership Enterprise listed on the Indonesia Stock Exchange. Analyze further whether these firms have changed tax avoidance activities since 2011-2015 when the Indonesian government enacted stricter auditing of tax regulation along with policy of company being responsibility to stakeholder in around companies. Our findings show that both corporate social responsibility and corporate governance are negatively significant associated with tax avoidance. These results indicate that policy of corporate responsibility can be influence policy of financial reporting through tax behavior. As we know many company will be considering lower tax costs to increase shareholder value through dividing profit after tax. Alongside company, government is also response through combining policy of tax and corporate responsibility in from a tax benefits, then companies and governments build and cooperate in creating a prosper public. Considering good corporate governance practice in every decision making will be facilitate company in planning tax policy by using tax benefits without harm government. We also report that corporate social responsibility can be increasing significantly firm value, because legitimate theories explain that by participating from the company to stakeholders, this will be increasing shareholder value. Another results is how corporate governance negatively affects significantly with firm value. This is signs that corporate governance in state-owned enterprise cannot be work well, because there is a lot of political interest regarding for taking policy in manage state-owned enterprise. Furthermore, our results suggest that firm arrange tax policy will get tax benefits through higher profit after tax, and then investor will be encouraged where the value of company will be increasing in the market.
\end{abstract}

\section{KEY WORDS}

Corporate social responsibility, corporate governance, firm value, tax avoidance, stateownership enterprise.

In an uncertainty market, the higher competition of each company in gaining market will change the company to be more responsive to opportunities by utilizing the environment around the company. Therefore, companies are required to adopt a Corporate Responsibility model that is not only related to economic aspects, but also needs to pay attention to environmental, social and legal aspects as a way to maintain the company's sustainability. However, in current business practices, the Corporate Responsibility model is adopted by companies such as "double-edged sword". On the one hand, it impacts company value because it can be used as a signal for investors to invest, but on the other hand, unwittingly, will increase tax saving activities, either intentionally (Tax avoidance) or unintentional (Tax Evasion).

The implementation of Corporate Responsibility which is increasing the value of the company also needs to be considered related to the company's tax policy, as this is comparable to the company's reputation risk. A plan that needs to be incorporated with a comprehensive corporate finance policy is required, so that it does not have a serious impact on the reduction of the tax burden to be paid to the government. Thus, companies need to consider tax planning that meets expectations by avoiding corporate sanctions and fines in tax planning without removing Corporate Responsibility policies to stakeholders and shareholders. Different targets between companies and governments are a problem at this 
time. The question is what will be facilitated by the government to keep the company accountable through its role that will affect good business practices, because good business practices depend on how the company becomes responsive in the market environment through stakeholder and stakeholder engagement. The same question is also given to the company that how the company enhances its corporate value through Corporate Responsibility together with considering the tax aspects that will affect dividends. The author argues that the achievement of absolute responsibility is a must, because the company that is still the organization that has the main goal is to increase the value of the company through social branding and also avoid the high tax costs and also to increase capital gains in the form of dividends.

Provisions concerning the obligation of private taxpayers have been regulated in Law No. 36/2008 article 2, paragraph (1) letter b (Income Tax Law). The Company as a taxpayer is obligated to pay tax in accordance with the provisions of Indonesian taxation regulations, which is calculated from the amount of net profit before tax multiplied by the prevailing tax rate. However, payment of taxes in accordance with the provisions will be contrary to the main purpose of the company, which is maximizing profits so the company tries to minimize the cost of taxes. The way that companies can do is through tax planning or aggressive taxes. Mangoting (1999) states that the tax is considered a cost to the company, so the need for efforts or strategies to minimize the costs incurred to pay taxes (tax planning). Tax planning is intended to minimize tax costs and maximize profits. Tax planning can be done by legal means in tax avoidance efforts called tax avoidance, whereas if done illegally called tax evasion (Mangoting, 1999; Mangunsong, 2002; Harari et al., 2013). Indirectly, the company's activities in maintaining Corporate Responsibility activities result in tax avoidance actions that can give disadvantages for the government to achieve tax revenue target.

The relationship between good corporate governance and corporate social responsibility towards tax avoidance through tax planning can also be analyzed from the stakeholder theory literature. Companies can identify important actors available in the environment, such as institutions, or other stakeholders such as employees, customers and investors. This approach is to identify and manage impacts on corporate stakeholders and reduce costs to avoid adverse regulations, tax binding, or laws that negatively impact others. Through the concept of corporate social responsibility and corporate governance is expected to be a strategic business decision that so far does not provide a great distance between the interests of the company and its stakeholders, especially related obligations as a taxpayer. According to Chen et al., (2014), tax avoidance is an important corporate strategy. Traditionally, it is believed that tax avoidance represents the transfer of wealth from government to company and increases the firm value. Nevertheless, tax avoidance is not cheap for firms, since tax avoidance risks are direct costs, including implementation costs, reputation loss and potential penalties, etc. Thus, corporate tax avoidance has two competitive effects on the firm's value of negative and positive impacts. Although it is a transfer of wealth from the government to shareholders, other negative impacts not only come from the external as described above, but the internal situation can occur through agency conflicts between managers and outside stakeholders increase the likelihood of managerial diversion is minus corporate value.

The tax avoidance aspect as a result of corporate responsibility will be a potential additional variable of information that can be used by a company to make decisions in managing the company over the long term. The government as stakeholders should begin to realize that it is clear that the tax does not only serve as state revenue, but in other cases the tax function as regulator needs to be clarified and refined, so the government's dependence on taxes will be reduced but through the company, the government will encourage business activities to participate in national development.

Optimizing the control function can be done by providing tax incentives for companies to optimize the implementation of CSR and GCG. As a company, it will be a motivation to collaborate with the government as a common stakeholder to build the nation through GCG and CSR so that the benefits to the company are attractive to the stakeholders without reducing the liabilities to shareholders. Based description above, the author is interested to 
take the research as follows "The Effect of Corporate Social Responsibility and Corporate Governance on Corporate Value with Tax Avoidance as Variable Intervention" which is expected to describe the patterns and business practices that occur in Indonesia, especially in State-Owned Enterprise are listed on the Indonesia Stock Exchange.

\section{LITERATURE REVIEW}

Corporate Social Responsibility (CSR) Theory. The complexity of social problems has more complicated in the past decade and decentralization has made the concept of Corporate Social Responsibility (CSR) is expected to provide a new alternatives in poor society empowerment. The limited role of the state in solving social problems such as a more decentralized form of recognition of the role of the private sector has provided a great opportunity for the sector to contribute its resources to solve social problems. Thus, decentralization is a momentum relevant to the realization of CSR programs as a form of private sector involvement in poor society empowerment in order to solve their social problems they faced.

The company's commitment to maintain of CSR and information disclosure in financial reporting will bring big benefit or relevance with economic value of the company. The greater attention and CSR performance disclosure will be greater in providing economic benefits or the relevance of the company's economic value. Conversely, if the company's attention is less to the behavior and reporting of CSR performance, it will be give the small benefits gained. CSR emissions are treated as intangible assets that play a strategic role as a value creator for corporate shareholders.

Previous research in discussing the relationship between CSR and firm value suggests that not all CSRs will maximize the firm value in order to measure the market. Fiori et al., (2015) found that good CSR can reduce the share price of listed companies because this practice considers it an avoidable cost that reduces corporate profits. Other studies derived from Stuebs and Sun (2015) have been discussed differently from previous studies, they show that a significant positive relationship between corporate social responsibility and corporate reputation and will have better corporate performance. So, it can be concluded in form of hypothesis as following this:

$\mathrm{H}_{1}$ : Corporate Social Responsibility affect on tax avoidance.

Good Corporate Governance. The formulation of corporate governance definitions used by the Corporate Governance Forum in Indonesia (FCGI) also cites the definitions used by the Cadbury Committee. The FCGI defines corporate governance as a set of rules that define the relationships between shareholders, managers, creditors, government officials and other internal and external stakeholders in relation to their rights and responsibilities, or systems in which the company is directed and controlled. In addition, FCGI also stipulates that corporate governance goals are to create value added for stakeholders.

Companies must grow from the beginning to pay attention to every aspect of stakeholders. The concept of good corporate governance (GCG), which includes Transparency, Accountability, Responsibility, Independence and Fairness (TARIF) is a key element in the preparation of corporate fundamentals. Each element in the TARIF should be formulated and implemented in the company's activities as well as the company's management commitments. The investment company in terms of corporate governance will increase the value of companies that provide benefits to shareholders directly. Investors will continue to hunt and buy at a premium price on companies that have good corporate governance practices. The strength in GCG implementation becomes a competitive advantage for the company.

Interestingly, that there are various outcomes related to the influence of GCG on corporate value, the first research derived from Bansal and Sharma (2016) suggests that board size plays an important role in improving company performance. Another variable is the higher board of $f$ independence directors will result in lower return on equity (ROE), and also the audit committee has a significant relationship with the ROE so that GCG cannot be regarded as conclusive evidence that significantly affects the company's performance. This is 
the same study from Rossi and Nerino (2015) explaining that Corporate Governance positively impacts the company's performance through operating performance (ROE), but for Tobin's $Q$, it can degrade the company's performance. Another study talks about the relationship between state ownership and company performance from Yu (2013) has concluded that state ownership has a relationship with company performance through ROE, ROA, and also Tobin's $Q$. So, it can be concluded in form of hypothesis as following this:

$\mathrm{H}_{2}$ : Corporate Governance affect on tax avoidance.

Tax Avoidance. Tax avoidance can be considered as tax evasion by following existing laws (Annisa and Kurniasih, 2012). Tax avoidance is undertaken in an unreported or reported manner but not in accordance with the actual situation on taxable income. In avoiding taxes, the taxpayer does not clearly violate the law or interpret the law but is inconsistent with the intent and purpose of the legislator. Tax avoidance activities undertaken by company management are conducted solely to minimize corporate tax liability. Tax avoidance is considered legal and makes the company have a tendency to do various ways to reduce the amount of revenue reported in the financial statements, so that any major taxes will also decrease. However, tax avoidance activities by companies can plague the company itself if they are not careful in their tax planning.

According to Balter and Mortenson (cited from Zain, 2008) explains the notion of tax avoidance as activities related to the determination of the show performed by the taxpayer (successful or not) to reduce / remove all the company's tax debt by paying attention to presence / absence tax consequences arising out. Meanwhile, Suandy (2008) states that tax evasion is engineered "tax affairs" which are still within the framework of taxation regulations. Tax avoidance is undertaken by corporate management to minimize corporate tax liability (Khurana and Moser, 2009). Paying taxes is also an important way for companies to engage positively with society. Tax avoidance is not in accordance with good corporate citizenship or CSR. Taxpayers must contribute to supporting the government in proportion to their abilities. However, it appears that businesses are not applying the CSR approach to taxation, but mention activities related to aggressive tax planning or tax avoidance.

Previous research has shown different results to measure the effect of CSR on tax avoidance or vice versa. The first study by Lanis \& Richardson (2013), they found that there is a statistically significant and statistically significant relationship between CSR and tax aggressiveness, so socially responsible companies tend to be less aggressive in terms of taxes. This research is also supported by Laguir et al., (2015) explaining that in fact, the aggressiveness of taxation depends on the nature of CSR being activated, more specifically, the higher the social dimension of CSR will be the lower tax aggressiveness level. Another study from Lanis \& Richardson (2013) found a different result from previous studies, which found that a statistically significant and statistically significant relationship between tax aggressiveness and CSR disclosure through the theoretical side of legitimacy. What does it mean? There are many studies that do not provide answers about the phenomenon of CSR relations and tax aggressiveness itself.

Corporate governance will always play an important role in "tax elasticity". For example, the report (PWC) on good governance does not mention activities related to compliance with tax obligations. The agency principle knows whether there is a harmony of interests between shareholders and management that takes them to the same side to look at tax issues. If the board of directors also obtains a share of the company's ownership or has a salary or other allowance related to the company's tax performance (tax savings), such as directors' compensation relating to the average effective tax rate or profitability of the company after tax, so they have an alignment of interest regarding tax planning. As a result, shareholders and the board of directors will provide structure compensation packages for directors to act in the interests of shareholders. However, it is also advisable that since aggressive taxes affect relative to corporate value, councils tend not to offer strong incentives to push directors into aggressive taxes. As we know that shareholders may or may not like directors to be aggressive, they like it only if the expected profit from avoidance is greater than reporting honestly. Shareholders will take risks, if management actions cannot receive tax deduction benefits and therefore they can prevent directors as management 
representatives acting aggressively because they do not think they can get benefit if there is no good governance.

Previous research from Koanantachai (2013) suggests that corporate governance is positively associated with tax avoidance, which means that firms with good governance pay less taxes than corporations with poor governance. Another study comes from Zhou (2011) requesting a company with a higher percentage of controlling shareholding and higher equity ownership tends to be more aggressive, but tax aggressiveness is reduced if the controlling shareholder is the government. And recent research by Mulyadi and Anwar (2015) found a mixed correlation with tax management. They point out that the board of directors compensation and the board of directors consistently shows a negative correlation with tax management as well as the number of boards that found a positive correlation with tax management.

Firm Value. Firm value is a description of the company's financial condition is analyzed by financial analysis tool, so it can be known about whether the company's poor financial condition that reflects the performance in a certain period. It is important that resources are used optimally in the face of environmental change. Assessment of financial performance is one way that can be done by management in order to fulfill its obligations to the funders and also to achieve the goals set by the company. If the performance is good then the business value will be high. With high business value will make investors look investing so will raise the stock price. This research has given several factors that will be used to measure company value, these factors are PER and Tobin's Q. In PER valuation theory is one approach that can be used by investors in assessing investors in stocks. Assessing an investment is a business that an investor can do to find a stock at a very low price compared to an intrinsic value. Assessment is required by the investor to make the right investment decision so as to produce the expected return of the selected stock. Many researchers argue that if an investor buys a stock at a price below from its instrumental value, the stock price will be close to its instrumental value. Otherwise, if the investor buys a stock at a price above the intrinsic value of the same price will fall close to its intrinsic value. Furthermore, fundamental investors believe that intrinsic value can be estimated by depicting fundamental variables of stock or company. Investors are looking for shares that are now undervalued or underestimated by the market and are not recognized by most investment communities.

Tobin's $Q$ is a measure to determine the market value of a company. $Q$ ratio is an indicator variable that is used to measure the performance of the company from an investment perspective. This ratio shows current market financial estimates of the value of additional investment returns. If the $Q$ ratio is above 1 (one), then investment in the asset will produce profit that gives higher value than the cost, so that will stimulate new investment. But if Mutual Fund is below 1 (one), investment is not integrated in asset (Herawaty, 2008). A larger $Q$ ratio indicates that the company has good development prospects that will reflect the value of the company. This point of view can be shown as how many investors will sacrifice to own the company. It is generally expected that shareholders prefer tax aggressiveness because the profits will be derived from tax aggressiveness (Chen et al., 2014). Paying less taxes implies that the company saves money to be transferred from the government to its shareholders. In addition, many corporate costs for highly manipulated transactions may flow into their pockets and not shareholders. Thus, the reduction of indirect tax costs will have an impact on higher after-tax profits, which can be used as dividend payout to shareholders, as well as retained earnings used to increase the company's investment either through finance or the real sector.

In contrast, this theory is not supported by previous research from Wahab and Holland (2014) which explains a significant negative model between corporate value and tax planning. They asserted that higher tax planning would make the company's value lower in order to risk investigating the tax officer afterwards. Shareholders will consider to determine the share of purchases from companies following tax planning. The wider range of rules in the field of taxation will make shareholders careful. However, another study from Lestari and Wardhani (2015) found that there is a positive relationship between tax planning and firm value. With reduced tax costs, cash flow will be much better to signal to investors to invest in 
the company. This is also supported by investor's knowledge of tax compliance is very low so that by focusing on corporate tax compliance tax which is an intangible asset becomes a criterion for investors in addition to the income and balance of a healthy company. Thus, it can be concluded in forming the following hypothesis:

$\mathrm{H}_{3}$ : Corporate Social Responsibility affect on firm value.

$\mathrm{H}_{4}$ : Corporate Governance affect on firm value.

$\mathrm{H}_{5}$ : Tax avoidance affect on firm value.

Based on the above concept, it can be derived as hypothesis model and measurement indicator as follows:

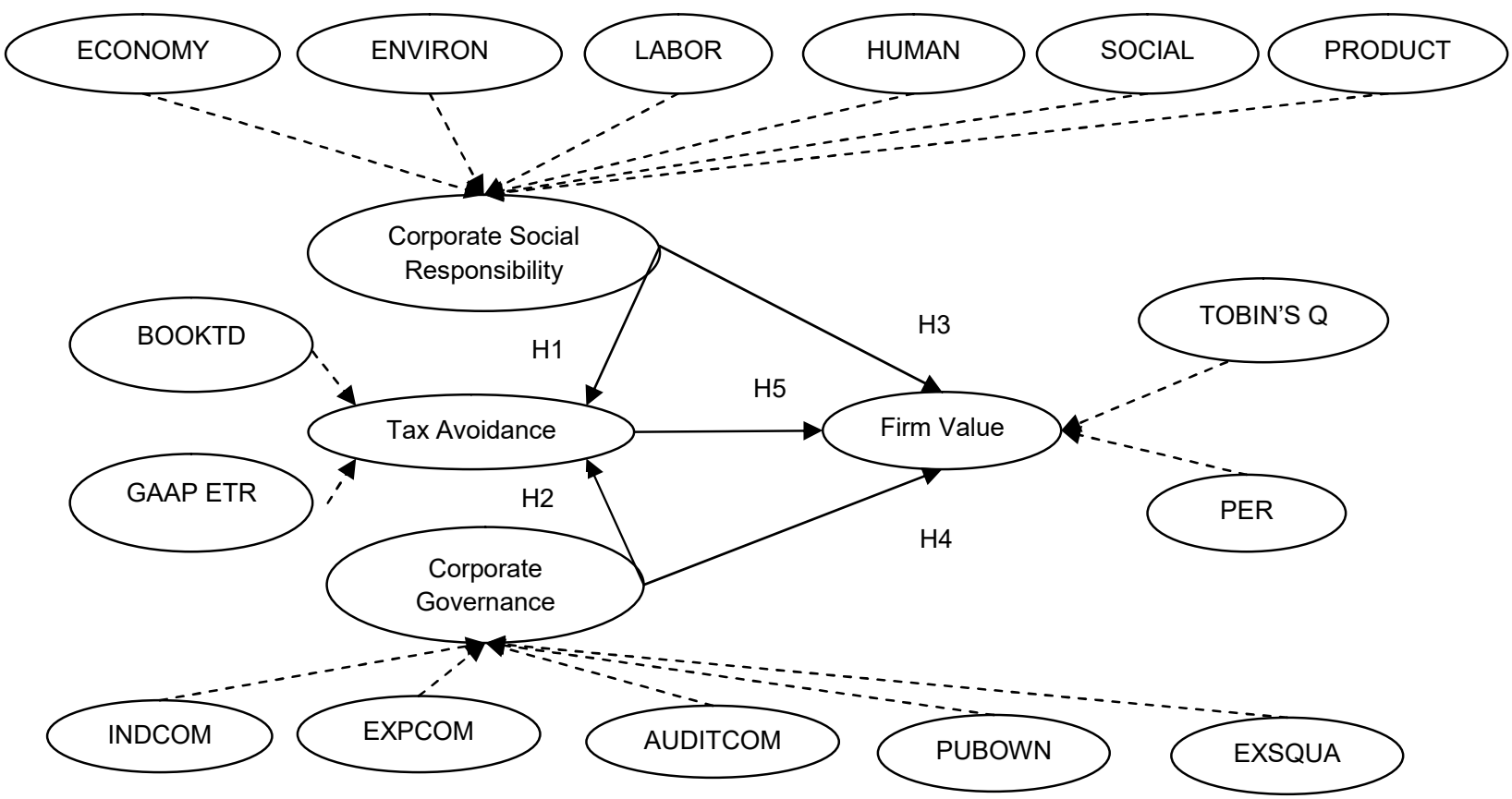

Figure 1 - Hypothesis Model

Notes:

- $\quad$ ECONOMY: Number of Total Disclosure CSRI in Annual Report (Economic) / Total Disclosure Economic;(Lanis \& Richardson, 2011).

- ENVIRON: Number of Total Disclosure CSRI in Annual Report (Environment) / Total Disclosure Environment;

- $\quad$ LABOR: Number of Total Disclosure CSRI in Annual Report (Labor)/ Total Disclosure Labor;

- $\quad$ HUMAN: Number of Total Disclosure CSRI in Annual Report (Human Right)/ Total Disclosure Human Right;

- SOCIAL: Number of Total Disclosure CSRI in Annual Report (Society)/ Total Disclosure Society;

- $\quad$ PRODUCT: Number of Total Disclosure CSRI in Annual Report (Product Responsibility) / Total Disclosure Product Responsibility;

- INDCOM: Number of Independent Commissioners;

- EXPCOM: Number of Commissioners Members who have background of Accounting or Finance (Armstrong et al., 2015).

- AUDITCOM: Number of Audit Committee, measure dummy in $<3=0, \geq 3=1$ (Annisa \& Kurniasih, 2012).

- PUBOWN: Number of public ownershipin $<40 \%=0, \geq 40 \%=1$

- $\quad$ EXSQUA: Measure dummy in, Available Transfer Pricing Document $=1$, except $=0$ (Ahmed dan Maounira, 2015)

- $\quad$ GAAP ETR: 25\% - (Tax Expense/Pretax Income) (Lestari \& Wardhani, 2015; Chen et al., 2014)

- $\quad$ BOOK TD: (Net Income - (Cash Tax Paid/25\%)) / Net Incom.

- $\quad$ PER: Stock Price / Earning Per Share (Amelia, 2010).

- $\quad$ TOBIN'S Q: ((Price Stock x Outstanding Stock) + Total Liabilities) / Book Value of Total Assets (Koanantachai, 2013; Chen et al., 2014; Lestari \& Wardhani, 2015).

\section{METHODS OF RESEARCH}

This research method is an explanatory research. Research on explanation or confirmatory research is a study that highlights the relationship between research variables and hypothesis test that has been formulated previously, therefore named also by testing the hypothesis or testing research (Sugiyono, 2011). The sampling technique used in this study 
is non-random sampling. This sampling method is recognized in which the random element of the population does not have the same opportunity to be selected as the sample. Hypothesis test using Partial Least Square (PLS). Partial Least Square (PLS) according to Wold in Ghozali (2008) is a powerful analytical method because it is not based on many assumptions. This research uses PLS as data analysis technique with SmartPLS software.

Based on the above considerations, the list of state-owned companies that listed companies in the Indonesian Exchange period 2011-2015 included in the sample criteria for this study are 20 companies. Furthermore, in relation to purposive sampling, the researcher must establish the requirement that it meets the criteria as follows:

- The company whose the main company always listed its shares on the Indonesia Stock Exchange in the period 2011-2015;

- The company whose the main company always raises the financial audit report period 2011-2015;

- The last is the company which has profit on 2011 until 2015.

Table 1 - List of State-owned Company

\begin{tabular}{|c|c|c|c|c|c|}
\hline \multirow{2}{*}{ No. } & \multirow{2}{*}{ Name of Company } & \multicolumn{3}{|c|}{ Sample Criteria } & \multirow[t]{2}{*}{ Sample } \\
\hline & & $\mathrm{I}$ & II & III & \\
\hline 1 & PT. Aneka Tambang Tbk & V & $\mathrm{V}$ & - & - \\
\hline 2 & PT. Bukit AsamTbk & $\mathrm{V}$ & $\mathrm{V}$ & $\mathrm{V}$ & V \\
\hline 3 & PT. AdhiKaryaTbk & $\mathrm{V}$ & $\mathrm{V}$ & $\mathrm{V}$ & $\mathrm{V}$ \\
\hline 4 & PT. Bank Negara Indonesia Tbk & $\mathrm{V}$ & V & $\mathrm{V}$ & V \\
\hline 5 & PT. Bank Rakyat Indonesia Tbk & $\mathrm{V}$ & $\mathrm{V}$ & $\mathrm{V}$ & $\mathrm{V}$ \\
\hline 6 & PT. Bank MandiriTbk & V & V & V & V \\
\hline 7 & PT. Bank Tabungan Negara Tbk & $\mathrm{V}$ & $\mathrm{V}$ & V & V \\
\hline 8 & PT. Garuda Indonesia Tbk & V & $\mathrm{V}$ & - & - \\
\hline 9 & PT. IndofarmaTbk & $\mathrm{V}$ & $\mathrm{V}$ & - & - \\
\hline 10 & PT. JasaMargaTbk & $\mathrm{V}$ & $\mathrm{V}$ & $\mathrm{V}$ & V \\
\hline 11 & PT. Kimia FarmaTbk & $\mathrm{V}$ & $\mathrm{V}$ & $\mathrm{V}$ & $\mathrm{V}$ \\
\hline 12 & PT. Krakatau Steel Tbk & V & $\mathrm{V}$ & - & - \\
\hline 13 & PT. Perusahaan Gas Negara Tbk & V & $\mathrm{V}$ & $\mathrm{V}$ & $\mathrm{V}$ \\
\hline 14 & PT. Pembangunan Perumahan Tbk & V & $\mathrm{V}$ & $\mathrm{V}$ & $\mathrm{V}$ \\
\hline 15 & PT. Semen Indonesia Tbk & V & $\mathrm{V}$ & $\mathrm{V}$ & $\mathrm{V}$ \\
\hline 16 & PT. Semen BaturajaTbk & - & - & $\mathrm{V}$ & - \\
\hline 17 & PT. Telekomunikasi Indonesia Tbk & $\mathrm{V}$ & $\mathrm{V}$ & $\mathrm{V}$ & $\mathrm{V}$ \\
\hline 18 & PT. TimahTbk & $\mathrm{V}$ & $\mathrm{V}$ & $\mathrm{V}$ & $\mathrm{V}$ \\
\hline 19 & PT. Waskita KaryaTbk & - & - & $\mathrm{V}$ & - \\
\hline 20 & PT. Wiiaya KaryaTbk & $\mathrm{V}$ & $\mathrm{V}$ & $\mathrm{V}$ & $\mathrm{V}$ \\
\hline \multicolumn{5}{|c|}{ The number of sample that is fulfill criteria } & 14 \\
\hline \multicolumn{5}{|c|}{ The number of sample that was analyst } & 20 \\
\hline
\end{tabular}

Source: Indonesian Stock Exchange 2011-2015.

\section{RESULTS AND DISCUSSION}

Data analysis techniques used in this study using partial least square (PLS) with smartPLS software. PLS is one of Structural Equation Modeling (SEM) that is able to analyze latent variable, indicator variable and measurement directly. The hypothesis test in the PLS analysis uses the t-test and is briefly described in the table following this:

Table 2- Hypothesis Testing Result

\begin{tabular}{llllll}
\hline $\mathrm{H}$ & Relationship between Variables & Path & t-statistic & Description \\
\hline 1 & $\left(\mathrm{X}_{1}\right)$ CSR $\rightarrow$ & $(\mathrm{Z})$ Tax Avoidance & -0.189 & 30.703 & Significant \\
\hline 2 & $\left(\mathrm{X}_{2}\right)$ GCG $\rightarrow$ & $(\mathrm{Z})$ Tax Avoidance & -0.637 & 148.331 & Significant \\
\hline 3 & $\left(\mathrm{X}_{1}\right)$ CSR $\rightarrow$ & $(\mathrm{Y})$ Firm Value & 0.414 & 88.598 & Significant \\
\hline 4 & $\left(\mathrm{X}_{2}\right)$ GCG $\rightarrow$ & $(\mathrm{Y})$ Firm Value & -0.128 & 13.810 & Significant \\
\hline 5 & $(\mathrm{Z})$ Tax Avoidance $\rightarrow$ & $(\mathrm{Y})$ Firm Value & 0.026 & 3.713 & Significant \\
\hline
\end{tabular}

Source: Data that have been processed by SmartPLS. 
Based on table the results of hypothesis testing in this study are as follows:

$H_{1}$ : there is a significant effect between Corporate Social Responsibility toward Tax Avoidance. Consistent with this study that a negative relationship between CSR disclosure and tax avoidance in this study have been received in the same manner as described previously (Xu and Zeng, 2015). They found that high levels of CSR disclosure were associated with low corporate tax aggressiveness. And this study is consistent with research conducted by Hoi, Wu and Zhang (2013) who investigated the relationship between CSR and tax evasion. Corporate socially irresponsible corporations are more likely to engage in aggressive tax evasion. This implies that the company's contribution to environmental responsibility may receive favorable tax treatment and thereby reduce its tax liabilities, for example R \& D expenditure can be tax deductible.In Indonesian tax laws, it can be seen that the government provides a special incentive whereby if the company does this activity directly into tax deductions. This finding is inconsistent with previous observations above that some socially responsible companies are also involved in tax-aggressive activities. Indeed, by engaging in CSR activities related to business conduct, companies develop a culture that promises ethical behavior to external audiences, and this increases profitability through tax planning activities (Laguir et al., 2015). Furthermore, according to Lanis \& Richardson (2013) explains that aggressive corporate taxes have clear CSR disclosures to alleviate potential public concerns arising from the negative impact of their tax aggressiveness on society, and show that they meet people's expectations in other ways. For this research, it is known that the tax decision is an indication of corporate characteristics or management behavior.

$\mathrm{H}_{2}$ : there is a significant effect between Good Corporate Governance toward Tax Avoidance. These findings are consistent with the results of previous studies, Koanantachai (2013) found that corporate governance is statistically significant and statistically significant to the tax rate. Companies with good governance tend to be less tax-paying than companies with poor governance. The functions of the board of commissioners and auditors incorporated in the corporate governance index are statistically significant against tax avoidance. Possible explanation is that the commissioner of expertise leads the company and is able to make decisions regarding tax management. Meanwhile, Zhou (2011) requested that tax aggressiveness can be reduced if the controlling shareholder is the government. It is mean that government intervention through shareholder ownership will reduce tax avoidance. Contrary to previous research, according to Armstrong et al., (2015) found that management expects a personal gift of grate from increased tax avoidance. He found evidence that equity incentives risk positively related to tax evasion and this association is larger on the right side of tax avoidance distribution. The role of an independent board of commissioners, commissioners' expertise, the quality of the external auditor will save the company to measure the transparency information associated with the financial information company in particular. Huseynov and Klamm (2014) explains that tax avoidance activities aim to reduce financial flexibility and increase the uncertainty of future profitability of the company, and this leads to an increase in information asymmetry among shareholders. Furthermore, examines how transparency of financial reporting and company quality varies with corporate governance. The results show that good governance characteristics can lead to improved reporting and financial transparency. One can conclude that if a company has the ability to improve governance or take the highest government, it affects the highest transparency and can directly reduce tax evasion. Thus, the study has shown the reality of management policies in the company.

$\mathrm{H}_{3}$ : there is a significant effect between Corporate Social Responsibility toward Firm Value. Consistent with Stuebs \& Sun (2015) said that who consider that CSR has a positive impact on reputation and reputation that is considered to have a positive impact on performance is often used as a motive to justify and encourage CSR investment activities. Then it will be concluded that the company can do well (increase the value of the company) by doing good CSR practices. From stakeholders, it can be seen that stakeholders can be even more correct that companies capable of managing other stakeholders, they can certainly manage the company for the future, especially for state-owners enterprise. However, this study distinguishes the results of Fiori et al., (2015) has found that a good 
CSR will reduce the stock price of listed companies. They assume that the effects of CSR costs are perceived as attributes of negative value, because this practice is like a cost that can be avoided in reducing corporate profits. It is mean that the marginal effect of CSR spending is the decrease in shareholder income as well as the value of the company directly. Furthermore, from these results can be evidence of the influence of signal theory that is a longer relationship between CSR and corporate value. CSR can serve as a signal for developing countries who want to assess foreign direct investment proposal by foreign companies not known.

$H_{4}$ : there is a significant effect between Good Corporate Governance toward Firm Value. This study is consistent with previous research that revealed good corporate governance (GCG) will result in lower corporate values through negative relationships. Research conducted by Basal and Sharma (2016); Rashid et al., (2010); Basyith et al., (2015) have found independent commissioners, as well as audit committees having negative relations with company value. The reason is that independent parties are inversely proportional to company value because the benefits of monitoring large parties are comparable to issues related to asymmetric information enhancement and will likely have higher coordination costs, which reduces effective monitoring. Furthermore, in Indonesia, most state enterprise management companies are solely appointed in accordance with kinship and also personal interests that are still questionable for their independency. Sometimes, it also does not consider the expertise, therefore it can be assumed that the independent party cannot perform the function and role appropriately because it is only a symbolic position, the different goals between management and independent parties will be the agency costs to consider from shareholders.

Contrary to this research, $\mathrm{Yu}(2013)$ requested that companies dominated by various state players would be easier to gain respect from the market and tend to outperform, because in a market that always operates openly and fairly, and this gives politicians the ability to deliver the best with privileged access to resources. It could be a problem if politicians use dominance in controlling the market for personal gain and the role of management can be superior through the support of politicians to operate the company in unfair market practices. Furthermore, the independent role of independent councils, audit committees, and external audits can be important in terms of management control to uphold financial discipline, promote well-regulated security markets, and build professional capacity and transparency for activities business. As already revealed by Rossi and Nerino (2015) that corporate governance through independent parties has a positive impact on corporate performance. Indeed good governance leads, at least potentially to efficient and nonspeculative management behaviors that can lead to the market value of the company is lower in a short time, but at the same time operating performance is better.

$\mathrm{H}_{5}$ : there is a significant effect between Tax Avoidance toward Firm Value. Consistently this research with Wang (2010) has found that there is a positive relationship between tax avoidance and firm value, but must be supported by the transparency of the company to manage business activities. Company transparency refers to 2 (two) criteria that is external information and internal information. These results indicate that the role of tax avoidance oversight to increase shareholder wealth is primarily driven by external and internal components of transparency. That is, companies intensively followed by information mediators such as financial analysis, institutional intermediaries have more credibility in providing information available to outside investors and thereby ensuring managers to conduct tax avoidance activities primarily to increase shareholder value. On the other hand, internal transparency in which managers have relatively greater control in providing limited information for outside shareholders to reduce their concerns about hidden agent costs associated with tax evasion activities. It's mean that actually there is a positive relationship between tax avoidance and corporate value.

However, this is not supported by previous research published by Chen et al., (2014), it has found that the increase in tax avoidance tends to reduce the level of corporate value. Honestly, Investors are not putting a premium on tax avoidance because this type of activity can disguise the behavior of managers and this is an illegal activity that is subject to legal 
sanctions. By taking the basic theory, signaling theory can be explained that investors should know about the planning and quality of the company's managerial organization related to tax policy in the company. Furthermore, investors should know about the risk mitigation that occurs, if the tax policy fails. Assidi et al., (2016) has concluded that there is a negative relationship between the optimization of corporate tax and corporate value, it indicates that tax rate minimization has a direct impact on the form of profitability.

\section{CONCLUSION}

The negative significant relationship between Corporate Social Responsibility (CSR) and tax avoidance in the state owner enterprise in Indonesia. Practically, this means that increasing of indicator of GRI such as economy, environment, labor, human right, and also social, which in this research are considered as indicators of CSR, will not be followed by the increasing tax avoidance. It can be caused that government have prepared provision in related on CSR expense that commit as tax deduction. So that, management of company can be choosing in kind of CSR expense as business strategy. The company have to able to manage cash which when is used for shareholder and when is used to promote product through CSR activity. Together with government, through maximizing facilitate of tax deduction, company it is not only keeping cash back for shareholder but company get good image from other stakeholder.

The results, corporate governance on tax avoidance, indicate significant influence with negative relation. It means that any increasing in corporate governance will affect the firm's tax aggressiveness of state owner enterprise listed in IDX. As we know, that the notion of state owner enterprise that is belong to government, it can be as duties in order to maximum service for society. State owner enterprise is not only running business practice, but it is also about complying and joining in developing country through tax. From this research, by practice of good corporate governance, it will directly affect to reduce tax aggressiveness. This is closely with agency theory whereby need to improve separation both of duty and responsibility between 4 (four) parties kind of government as majority ownership, minority shareholders, board (independent and non-independent), and also management. All parties have to posses same objective each other and working together through principle of good corporate governance.

Significantly corporate social responsibility influence on firm value in the state owner enterprise in Indonesia. Practically, this means that increasing of indicator of GRI such as economy, environment, labor, human right, and also social, which in this research are considered as indicators of CSR, will be followed by the increasing Firm Value. It is similar influential to the Firm Value variable proxied by Price Earnings Ratio. This is fulfill that the signaling theory is explaining about duty and requirement of management to shareholder that does only taking profit to shareholder wealth, while considering CSR expense that is affecting cash flow, moreover reducing transfers to shareholder, caused by increasing expense of company operation. it is directly influence for business in keeping sustainability on market.

The better of corporate governance (expertise commissioner, index auditor) is apparently making any firm value of state owner enterprise listed on the IDX not working well. In this research, it is precisely shown by the test which demonstrates negative relationship between the corporate governance on firm value that was measured by PER and TobinsQ. The corporate governance is not always influence firm value better, but it is oppositely depending on various and criteria about company itself.

Tax avoidance shows a positive significant influence on firm value of a state owner enterprise listed at the IDX. This finding support by signaling theory. It suppose that practice tax avoidance in the stock market is interest of investor. Investor will see company in complying with tax aggressiveness is running business well caused higher profit after tax as result of tax avoidance activities. Indeed, based on this research will be proven that the existing of external side will be suitable partner with management to more increasing firm value. As we know, the role of financial analyst and intermediaries institutional as external 
side have to suggest management to maximize grey area from tax role and making report of company future in supporting management performance. Temporarily, the role independence board and auditor in the state owner enterprise will be supporting by corporate transparency such as press coverage and dissemination of information.

The limitations of this study are:

- There are many criteria from state-owned companies that have been listed on the Indonesia Stock Exchange. As we know, in this study used tax rate requirements to measure effective tax rates or book tax differences of $25 \%$. Thus, it may affect the role of tax rates that the company must impose on itself. Of course, it could be a more valid result, if researcher can analyze and focus the state rating company that only imposed a tax rate of $25 \%$.

- Some data are not supported by Indonesia Stock Exchange. Some data has not been published quarterly so the researcher must calculate it manually. It has the potential risk of human error and also takes a long time to solve it.

- The use of indicators in this research model is still limited. In fact, many indicators that can be used as research material testing related to capital structure and financial performance.

\section{REFERENCES}

1. Amalia, H.S. (2010). Analisis Pengaruh Earning Per Share, Return On Investment dan Debt To Equity Ration terhadap Harga Saham Perusahaan Farmasi di BEI. Jurnal Manajemen dan akuntansi, 11 (2), 98-106.

2. Annisa, N.A., \& Kurniasih, L. (2012). Pengaruh Corporate Governance terhadap Tax Avoidance. Jurnal Akuntansi \& Auditing, 8 (2), 95-189.

3. Armstrong, C.S., Blouin, J., Jagolinzer, A.D., \& Larcker, D.F.(2015). Corporate Governance, Incentives, and Tax Avoidance. Journal of Accounting and Economics, 60, $1-17$.

4. Assidi, S., Aliani, K., \& Omri, M.A.(2016). Tax Optimazation and the Firm's Value: Evidence From The Tunisian Context. Borsa Istanbul Review, 16 (3), 177-184.

5. Bansal, N., \& Sharma, A.K. (2016). Audit Committe, Corporate Governance and Firm Performance: Empirical Evidence from India. International Journal of Economics and Finance, 8 (3), 103-116. DOI: 10.5539/ijef.v8n3p103.

6. Basyith, A., Fauzi, F., \& Idris, M. (2015). The impact of board structure and ownership structure on firm performance: an evidence from blue chip firms listed in Indonesian stock exchange. Corporate Ownership \& Control, 12 (4-3), 344-351. http://doi.org/10.22495/cocv12i4c3p2.

7. Chen, X., Hu, N., Wang, X., \& Tang, X. (2014). Tax avoidance and firm value: evidence from China. Nankai Business Review International, 5(1), 25-42. http://doi.org/10.1108/NBRI-10-2013-0037.

8. Fiori, G., Donato, F. di, \& Izzo, M. F. (2015). Corporate Social Responsibility and Stock Prices : a study on the Italian market. Corporate Ownership \& Control, 12(2), 600-609.

9. Ghozali, I.(2008). Structural Equation Modeling: Metode Alternatif dengan Partial Least Square. Badan Penerbit Undip. Semarang.

10. Harari, M., Sitbon, O., \& Donyets-Kedar, R.(2013). Aggressive Tax Planning and Corporate Social Responsibility in Israel. Accountancy Business and the Public Interest, $1-46$.

11. Herawaty, V. (2008). Peran Praaktek Corporate Governance sebagai Moderating Variable dari Pengaruh Earnings Management Terhadap Nilai Perusahaan. Jurnal Akuntansi dan Keuangan , 10 (2), 97-108.

12. Hoi, C.K (Stan)., Wu, Q., \& Zhang, H. (2013). Is Corporate Social Responsibility (CSR) Associated with Tax Avoidance? Evidence from Irresponsible CSR Activities. Accounting Review, 1-50. 
13. Huseynov, F., \& Klamm, B.K. (2012). Tax Avoidance, Tax Management and Corporate Social Responsibility. Journal of Corporate Finance, 18, 804-827. doi: 10.1016/j.jcorpfin.2012.06.005.

14. Khurana, I.K., \& Moser, W.J. (2009). Institutional Ownership and Tax Aggressiveness. Financial Accounting and Reporting Section (FARS) Paper, 1-43. http://dx.doi.org/10.2139/ssrn.1464106.

15. Koanantachai, R. (2013). Tax Aggressiveness, Corporate Governance and Firm Value: An Emerical Evidence From Thailand. Thammasat University, 1-37.

16. Laguir, I., Stagliano, R., \& Elbaz, J. (2015). Does Corporate Social Responsibility Affect Corporate Tax Aggressiveness?. Journal of Cleaner Production, 107, 662-675. https://ssrn.com/abstract=2617629.

17. Lanis, R., \& Richardson, G. (2011). The Effect of Board of director composition on Corporate tax aggresiveness. Journal of accounting and Policy, 30, 50-70.

18. Lanis, R., \& Richardson, G. (2013). Tax Aggressiveness and Corporate Social Responsibility disclosure: A New Test Of Legitimacy Theory. Accounting, Auditing, \& Accountability Journal, 26 (1), 75-100. doi: 10.1108/09513571311285621

19. Lestari, N., \& Wardhani, R. (2015). The Effect of the Tax Planning to Firm Value with Moderating Board Diversity. International Journal of Economics and Financial Issues, 5 (Special Issue), 315-323.

20. Mangoting, Y.(1999). Tax Planning: Sebuah pengantar sebagai alternatif meminimalkan pajak. Jurnal Akuntansi dan Keuangan, 1 (1), 43-53.

21. Mangunsong, S.(2002). Peranan Tax Planning dalam Mengefisiensikan Pembayaran Pajak Penghasilan. Jurnal Akuntansi, 2 (1), 44-54.

22. Mulyadi, M.S., \& Anwar, Y.( 2015). Corporate Governance, Earning Management and Tax Management. Global Conference on Contemporary Issues in Education in Las Vegas. Ocial and Behavioral Sciences, 177, 363-366.doi: 10.1016/j.sbspro.2015.02.361

23. Rashid, A., Zoysa, A.De., Lodh, S., \& Rudkin, K. (2010). Board Composition and Firm Performance: Evidence From Bangladesh. Australasian Accounting Business and Finance Journal, 4, 76-95.

24. Rossi, M., \& Nerino, M. (2015). Corporate Governance and Financial Performance of Italian Listed Firms. The Resuts of an Empirical Research. Corporate Ownership \& Control, 12 (2), 636-651.

25. Suandy, E. (2008). Hukum Pajak. Edisi 4. Jakarta: Salemba Empat.

26. Sugiyono. (2011). Metode Penelitian Kuantitaif Kualitatif dan R\&D. Bandung: Alfabeta.

27. Stuebs, M., \& Sun, L. (2015). Corporate governance and social responsibility. International Journal of Law and Management, 57(1), 38-52. http://doi.org/10.1108/IJLMA-04-2014-0034.

28. Wahab, N.S.A., \& Holland, K.M. (2014). The Persistence of Book-Tax Differences. The British Accounting Review, 47 (4), 111-124.

29. Wang, X. (2010). Tax Avoidance, Corporate Transparency, and Firm Value. Dissertation Faculty of the Graduate School of The University of Texas at Austin, 1-88.

30. Xu, B., \& Zeng, T.(2016). Profitability, state ownership, tax reporting and corporate social responsibility: evidence from Chinese listed firms. Social Responsibility Journal, 12 (1), 23-31, https: //doi.org/10.1108/SRJ-06-2014-0076.

31. Yu, M. (2013). State Ownership and Firm Performance: Empirical Evidence from Chines Listed Companies. China Jornal of Accounting Research, 6, 75-87. http://dx.doi.org/10.1016/j.cjar.2013.03.003.

32. Zain, M. (2008). Manajemen Perpajakan Edisi 3. Jakarta: Salemba Empat.

33. Zhou, Y. (2011). Ownership Structure, Board Characteristics, and Tax Aggressiveness. Master's thesis, Lingnan University, Hong Kong. Retrieved from http://dx.doi.org/10.14793/acct_etd.3. 